\title{
"If I had a million dollars...": The curious incident of a city, a forest, and sustainable anesthesia
}

\author{
Timur Özelsel, MD • Rakesh V. Sondekoppam, MD • Vivian Ip, MD • \\ Justine Klaver-Kibria, MSc • Cheryl Mack, MD
}

Received: 3 December 2018/Revised: 3 December 2018/ Accepted: 7 December 2018/Published online: 3 January 2019

(C) Canadian Anesthesiologists' Society 2019

\section{To the Editor,}

October $16^{\text {th }}, 2018$ marked the $172^{\text {nd }}$ World Anesthesia Day (WAD) in commemoration of the first demonstration of ether anesthesia ${ }^{1}$-an event that is still considered one of the most significant events in medical history. The specialty of anesthesia has advanced tremendously since then, and ether has now been displaced by better inhalational anesthetics. Despite all the benefits of inhalational anesthesia, all currently used agents are potent greenhouse gases (GHG) and contribute to global warming. ${ }^{2}$ Additionally, nitrous oxide is the most potent ozone-depleting agent in the atmosphere today. Edmontonbased members of the recently founded Section for Environmental Sustainability within the Canadian Anesthesiologists' Society (CAS-ES) planned to celebrate WAD by reforesting part of the Fort McMurray area with the number of trees necessary to offset one year of carbon dioxide equivalents (CDE) produced by volatile anesthetic agents used that year in the Edmonton zone.

To calculate the CDE of volatile anesthetics used, the global warming potential values for a 20 -year time period $\left(\mathrm{GWP}_{20}\right),{ }^{3}$ as published by the Intergovernmental Panel on Climate Change, were multiplied by the total weight purchased for the respective inhalational agents in 2017. The weight was calculated by multiplying the volumes (in $\mathrm{mL}$ ) by the volatile agent's density. In 2017, the Edmonton zone purchased 1,211,250 mL sevoflurane, $593,280 \mathrm{~mL}$

T. Özelsel, MD (凹) · R. V. Sondekoppam, MD · V. Ip, MD · J. Klaver-Kibria, MSc · C. Mack, MD

Department of Anesthesiology and Pain Medicine, University of Alberta, Edmonton, AB, Canada desflurane, $54,600 \mathrm{~mL}$ isoflurane, and $6,350,066 \mathrm{~mL}$ nitrous oxide. This resulted in 1,460,415 kg of CDEs for sevoflurane, $4,822,950 \mathrm{~kg}$ for desflurane, $147,000 \mathrm{~kg}$ for isoflurane, and $1,769,935 \mathrm{~kg}$ for nitrous oxide, totalling a CDE of $8,200,300 \mathrm{~kg}$ for the year. The volume of individual agents purchased and the calculation of total $\mathrm{CDE}$ can be seen in the Figure.

Using the online CDE conversion table from the United States Environmental Protection Agency, ${ }^{4}$ over 212,500 tree saplings would need to grow for ten years to offset the impact of volatile anesthetic agents purchased in 2017 in the Edmonton zone. A tree sapling costs CAD 8; therefore, over CAD 1.7 million would need to be raised to fulfill the goal set out by the Edmonton-based CAS-ES members. This goal proved too lofty; although 256 trees were planted with donations by anesthesiologists from the Edmonton zone.

This example perfectly demonstrates the problem anesthesiologists face today-i.e., a practice that cannot be feasibly offset with regards to climate change, and thus is unsustainable. Action must be taken soon and, ideally, will come from government regulation of the industry and from practice changes. Firstly, alternative inhalational agents without GHG potential need to replace those currently used. Xenon would be such an agent, ${ }^{5}$ and others could be developed if the need and benefits were passed on to industry through incentivization from the government. Capturing and recycling used anesthetic agents would be a major step, since an estimated $95 \%$ of the environmental impact stems from the release of agents into the atmosphere; the remaining 5\% comes from manufacturing and distribution of the agents. ${ }^{6}$ Secondly, anesthesia practitioners could minimize the use of the heaviest atmospheric pollutants (i.e., desflurane and nitrous oxide) and use low-flow anesthesia techniques. The 
Figure Year-wise comparison of the volume of inhaled anesthetic usage and the corresponding carbon dioxide equivalents $(\mathrm{CDE})$ in the Edmonton zone during 2016 and 2017

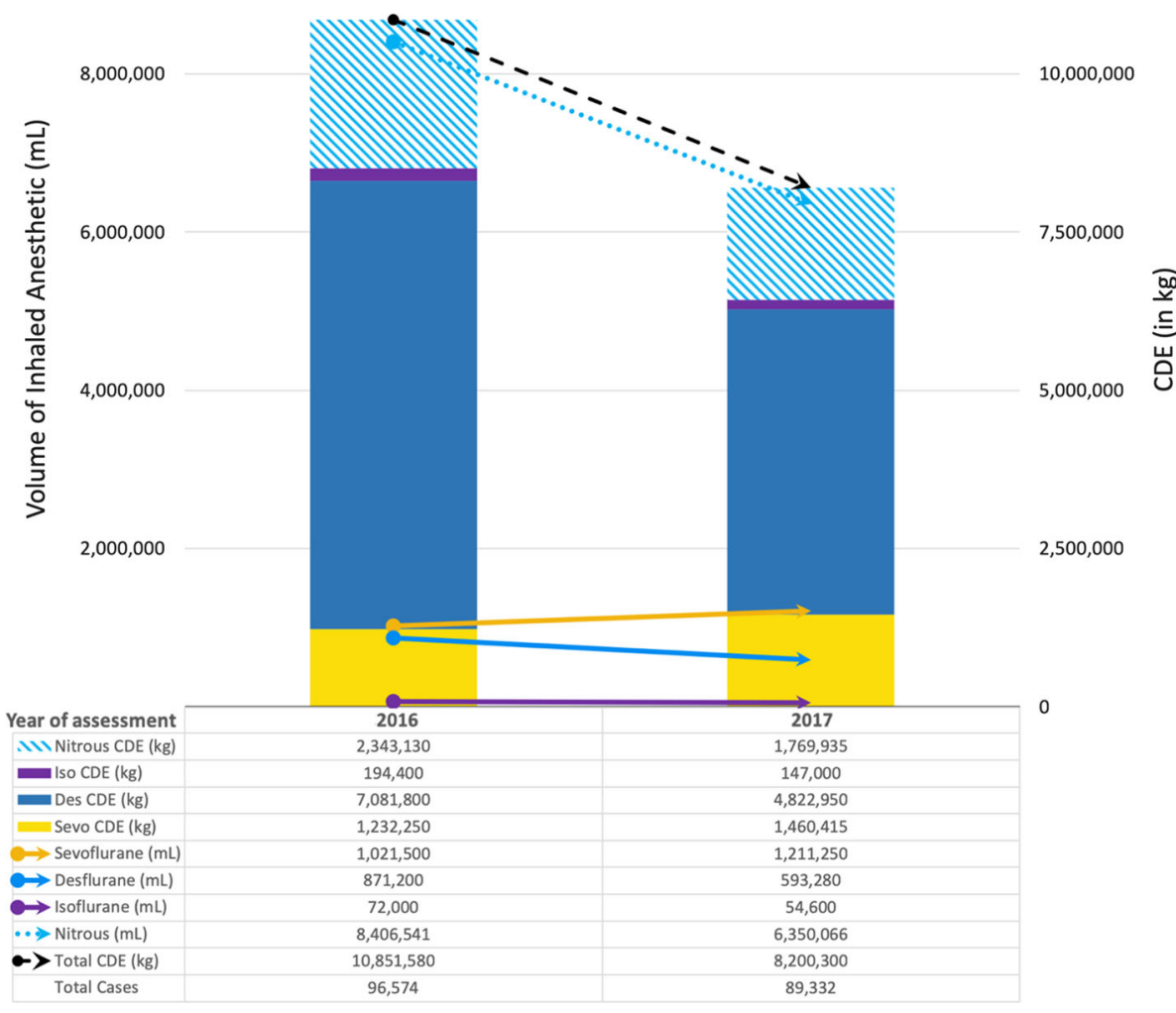

\section{References}

1. Haridas RP. October 16: Ether Day, National Anaesthesia Day and World Anaesthesia Day. J Anesth Hist 2017; 3: 115-6.

2. Özelsel TJ, Sondekoppam RV, Ip VH, Tsui BC. Re-defining the $3 \mathrm{R}$ 's (reduce, refine, and replace) of sustainability to minimize the environmental impact of inhalational anesthetic agents. Can J Anesth 2018; DOI: https://doi.org/10.1007/s12630-018-01279-3.

3. Myhre G, Shindell D, Bréon FM, et al. Anthropogenic and natural radiative forcing. In: Stocker TF, Qin D, Plattner GK, et al. (eds). Climate Change 2013: The Physical Science Basis. Working Group I Contribution to the Fifth Assessment Report of the Intergovernmental Panel on Climate Change. NY: Cambridge University Press, Cambridge; 2013.

4. United States Environmental Protection Agency. Greenhouse Gas Equivalencies Calculator - September 2017. Available from URL:: https://www.epa.gov/energy/greenhouse-gas-equivalenciescalculator (accessed December 2018).

5. Rossaint R, Reyle-Hahn M, Schulte Am Esch J, et al. Multicenter randomized comparison of the efficacy and safety of xenon and isoflurane in patients undergoing elective surgery. Anesthesiology 2003; 98: 6-13.

6. Sherman $J$, Le C, Lamers $V$, Eckelman $M$. Life cycle greenhouse gas emissions of anesthetic drugs. Anesth Analg 2012; 114: 108690.

Publisher's Note Springer Nature remains neutral with regard to jurisdictional claims in published maps and institutional affiliations.

Funding The manuscript was not funded. 